\title{
Work, Sickness, Absence, and Identity-Work
}

\section{Trude Gjernes'}

Senior researcher, Nordland Research Institute, Bodø, Norway

\begin{abstract}
This article explores how a group of industrial workers experience long-term sickness absence and how they cope with this situation. The article presents data from in-depth interviews with male industrial workers employed in a Norwegian factory. The findings suggest that the factory workers handle their failing health by engaging in activities other than wage work. They did not accept a social situation characterized by passivity, social isolation, marginalization, or loss of self. The workers reported that they lived active lives, reproducing social identities through different bodily activities. It was also made clear that the sickness absence was not a result of their choice, but a result of a failing body and the employer's inability to adapt work to their health situation.
\end{abstract}

\section{KEY WORDS}

Identity-work / industrial workers / interactionism / Norway / sickness absence

\section{Introduction}

ccording to the Central Statistics Bureau in Norway (SSB), the level of sick leave in Norway was $7.7 \%$ in 2009. Long-term (more than 12 weeks) sick leave is seen as more worrying than short-term absence. Indeed, prolonged leave is associated with a number of negative outcomes. Individuals risk poorer recovery, poverty, physical and mental health problems, and social exclusion or marginalization (Ose et al., 2006; Waddell and Burton, 2006). From the perspective of society, long-term absence because of illness represents a grave economic problem, and employers risk loss of experienced workers. Long-term sick leave is also associated with an increase in premature retirement because of disability (Blekesaune and Pedersen, 2006). Therefore, political efforts have been committed to reducing the level of sick leave and preventing employees from losing their bonds to working life. This has resulted in a major focus on absence from the workplace and measures at organizational and individual levels have been adopted to prevent long-term sick leave.

The major focus on sick leave from political authorities, media, and trade unions affects workplaces in public as well as private sectors. It has generated a negative cultural discourse on sick leave. The sick person who is absent from work has almost become a new modern outcast who needs to be registered and controlled. It has been argued that the level of long-term sick leave is related to diminishing work ethics in society, a thesis connected to the proposition that the Norwegian welfare pension system is too generous. Sickness absence has, in general, become negatively considered, a point underlined by Bellaby (1999) in his excellent book "Sick from work-the body in employment." This negative cultural discourse may influence and threaten the self-image of not only

\footnotetext{
${ }^{1}$ E-mail: trude.gjernes@nforsk.no
} 
employees on long-term sick leave who struggle with injuries, illness, and debilitating health problems but also those who after several periods of sick leave are partly or completely on premature retirement because of disability. This article explores a group of industrial workers' experience of long-term sickness absence and their creative strategies for coping with this experience.

Data for the article come from in-depth interviews with men working in a Norwegian factory producing fertilizer. The factory used to be a cornerstone employer in the local community a couple of decades ago, and it is still a central workplace there. The factory workers have physically demanding jobs, and their bodies have to be fit and adjustable to the work tasks that are demanded of them.

To become ill or injured is experienced as a new situation by workers who are used to be in good health and able to use their body as a working tool. The new condition has many consequences and it interrupts the habits and routines of the workers' everyday life; it also challenges their identities and embodied individual subjectivities. Their new situation might change their lives and result in what Mike Bury (1982) called a biographical disruption.

How people handle such new situations depends on different circumstances, and to study the characteristics of how people respond to such situations is of vital importance to our understanding of changes in social life (Shilling, 2008). Following pragmatist theory (Shilling, 2008) and interactionism (Atkinson and Housley, 2003), I argue that when ordinary habits and routines are interrupted because of bodily problems and incapacities, people may not respond passively. Instead, they seem to use their creativity to rearrange their lives within the frames of new circumstances, hold on to identities or personal character traits important to them, and in new ways pursue the meaning of work and being active.

A number of studies have already explored the ways identity is managed by individuals at work (Allen Collinson, 2006; Collinson, 2003; Riach and Loretto, 2009) and how people with chronic illnesses work with their identities (Bury, 1982; Charmaz, 1994, 1999, 2000; Kelly, 1992). Even though some have demonstrated how people who fall out of working life struggle economically and socially and continuously work with their identities, few have focused on how employees experience long-term sickness absence and how they seek to maintain or reconstruct acceptable identities. This article analyzes how industrial employees work with their identities and try to maintain an acceptable image of their self while ill and on long-term sickness absence.

The data presented here suggest that many factory workers on long-term sick leave handle their new social situation caused by failing health and bodily incapacity by engaging in other activities than waged work. The main argument of the article is that even if the workers on long-term sick leave interviewed by us had to leave work, temporarily or permanently, they did not accept a situation characterized by passivity, social isolation, and marginalization or loss of self. On the contrary, they reported to live active lives and seemed to reproduce their social identities by engaging in various bodily activities. As their bodies were the key to employed work, their bodies were also the key to developing acceptable and alternative forms of life when they were absent from work because of health problems. It was also emphasized that a situation of ill-health and sickness absence was not a result of their own choice; they were forced into this situation by two reasons: the failing body and the employer's inability to adapt work demands to the workers' health situation. 


\section{Theoretical framework}

According to Marx and Engels (1970), the body is our most fundamental working tool. It is also a major device for producing or presenting identity and it is through the body that we experience the world and our self. As a biological entity capable of physical work, as display of identity, and as center of our experiences, the body is in a continuous process of becoming. This process is affected by work and activity (Blaxter, 2004; Bloor, 2011; Marx and Engels, 1970; Shilling, 2005; Wolkowitz, 2006). Some bodily activities are seen and experienced as positive and some as negative. In general, physical activities and wage work are considered as positive bodily activities that are visible to oneself and others.

Within our culture, physical activity is in general considered as positive. It has increasingly become a central and marked value in contemporary society as it is related to public health, well-being, and leisure events (Bloor, 2011). Some physical activities are considered as negative because they cause harm to the body. It is particularly so when the harm is known and considered as morally or legally unacceptable as, for instance, physical violence. What counts as valuable physical activities is culturally determined.

Wage work is considered to be a valuable kind of activity at least in three ways. Firstly, wage work is a prerequisite for income. Wage work makes us financially independent, it turns us into producers and contributors, and it creates order in our own life. It is a guarantee for adequate participation in the larger orderly social system. To be unemployed is a threat to an adult's standing in society. This conclusion can be derived from several studies. Among these is an early but still highly relevant study by the Norwegian anthropologist Cato Wadel (1973). He showed how the unemployed George worked hard to maintain his standing in his local community by engaging in different types of activities available to him in his local setting. Secondly, wage work structures time and life for between 30 and 50 years of a person's life. To attend a job every working day means to let the timetable of the job generate order in the individual worker's life. It also creates order in the family's life and for the larger society. It makes our everyday life predictable and ordered.

Thirdly, which is a major issue in this article, work also says something about who we are. According to Miller and Rose (2008), wage work has been a key site to the formation of persons. Doherty (2009), Felstead et al. (2005), and Shilling (2005) argue that work is a central part of our identity and fulfills important personal and social needs. The workplace is an important locus of social relations and for experience of social identity and belonging. This comprehension has been opposed by scholars such as Bauman (1998), Beck (1992, 2000), and Sennet (2004), who argue that wage work plays a less significant role today compared with earlier periods. According to Bauman (1998, p. 32), we live in a consumer society where work has lost the prominent position it had in earlier times when society concentrated on production. Hence, consumption, not work, should be what is essential to our identities. In this article, I comply with Shilling (2008) and other scholars mentioned above who argue that wage work still has a prominent position in our society, that production is significant in several ways to individuals. Wage work is among the most visible signifiers of identity and self. To be left out of working life is therefore a threat to an individual's identity and self. 
Identity and self have been defined a bit differently by different scholars within interactionist traditions (Atkinson and Housley, 2003). In this article, the understanding of identity and self is drawn from interactionists such as Kathy Charmaz (who largely builds on symbolic interactionism) and Goffman and pragmatists like Chris Shilling. According to Charmaz (1994, p. 37), identities "will define, locate, characterize, categorize and differentiate self from others." Individuals have several identities related to their roles such as father, sailor, mother, employee, or employer. If unable to act according to role demands, identities might be threatened. The threat comes not only from the individual but also from others. Identities need to be confirmed by the individual and by others (Cooley, 1998; Goffman, 1969; Mead, 1934). According to Charmaz (1999; quoted in Kelly and Millward, 2004, p. 2), self "refers to all those qualities, attributes, values and sentiments, including feelings of moral worth, that a person assumes to be his or her own." Following interactionism, identities and selves develop through socialization which is a lifelong process (Charmaz, 1983). It does not stop after childhood. It confines through adulthood and takes new ways with aging or with long periods of illness or chronic diseases or other kinds of life crises. Identities develop through the forms of interaction individuals take part in and how they adjust to their surroundings (Shilling, 2008). Identities and selves are therefore considered to be processual, changeable, and in constant flux, but they still have a stable core that is reproduced in various ways through the life span (Kelly and Millward, 2004; Shilling, 2008).

Threats of identities might encourage identity-work. Identity-work is for instance induced when biographical disruptions following ill-health occur. Identity-work is also induced when individuals experience serious disruptions of their ordinary life habits or negative changes of their bodies. Following Parsons et al. (2008, p. 1831), identity-work is understood as "the active engagement, effort and agency recounted by respondents." It is directed toward coming to terms with changes brought on by illness, changes in how actors view themselves, and how they believe others view them. Identity-work is performed in order to describe who you are, who you are not, and who you want to be (Parsons et al., 2008). The question is how industrial workers work with their identity and self when caught within the frames of long-term disabling illness?

Wage work might lead to accidents and ill-health and exploit the body. The body is the industrial employee's fundamental capital, but hard physical work may reduce this capital, and when the body loses working capacity the body loses value and the fundamental condition for waged work vanishes. For those who are out of productive work on permanent basis, it means a significant loss of income. They have to restructure their lives because of that. In addition, they risk a significant social loss and a threatened identity. Identity-work may therefore be necessary to withhold acceptable identities and a respectable self. However, even if a body loses the working capacity demanded by working life, it might still have capacity to take part in corporal activities outside the waged work context (Shilling, 2005; Wolkowitz, 2006). It follows from this that the consequences of ill-health are relative and that lack of waged working capacity that excludes employees from their workplace does not necessarily exclude them from other types of work and physical activities. Although employees are incapable of conducting their job at the factory or workplace because of ill-health they might still be able to engage in other types of work or physical activities. This will be described after the following method section. 


\section{Method}

The data used in this article are drawn from a larger study (Gjernes and Pettersen, 2009) of the degree to which employers adjusted the work situation for employees with health problems that resulted in long-term sick leave, and if those adjustments were made in a manner that allowed the employees to return to work. Data for this article are based on interviews with male employees from a Norwegian industrial enterprise who had experienced long-term sick leave.

\section{Sampling}

Data come from 21 separate in-depth interviews with male workers. Nineteen of them were still employed when interviewed and two had recently received premature retirement because of disability. Safety deputies and union officials were also interviewed. In addition to the employed men, five employers and leaders of the enterprise were also interviewed. The interviews lasted from 45 to 130 minutes. The interviews were conducted at the industrial enterprise by the author. The participation requests were sent via the employer and the company's health care service to every employee (approximately 25 persons) who had experienced a long-term sick leave during the last two years. A total of 21 employees agreed to participate after signing a written consent. We were informed by the employer that the 21 employees signed the consent without hesitation when informed about the study and asked to participate. According to the company's health care service, their cooperation with the employees was experienced as trustful and satisfying. This trustful relationship might have influenced the positive response form the interviewees. It is possible that self-selection among the employees has affected the information we have about the workers and experiences of long-term sickness absence. It is difficult to know in what sense our data might be biased, but it has been impossible to recruit interviewees in other ways because of ethical and legal principles. But all our interviewees have the experience we needed data about. They are relevant for our study.

The interviews were open, but structured by an interview guide that covered a range of topics related to the reasons for each sick leave. The guide also covered questions about how the employees experienced long-term sick leave, and for some interviewees attention was drawn to how they experienced having premature retirement because of disability. Finally, the interview guide asked interviewees to characterize their work situations and social life prior to their sick leave as well as to their life forms today. They were also asked to describe their thoughts about the measures implemented at their workplace to make return to work possible for them after longterm sick leave.

\section{Data Analysis}

We interpreted the accounts given by the interviewees about how they spent their days when they were on sick leave, their opinions about their job and their working environment, and their thoughts about the relationship between their health and their 
working conditions. These topics were important because they might reflect personal, social, and moral aspects of identity. In general, the interviewees described themselves as active and engaged individuals. When reflecting on our questions, the respondents referred to their own experiences. At the same time, they also drew on and responded in accordance with what may be seen as general and cultural discourses about or attitudes to sick leave and work ethics. This was especially true when they described their health problems, their work, and what they were doing when they were on sick leave or premature retirement because of disability. It also meant that responses to the interviewer's questions might be heard as accountings or legitimating responses, directed to the interviewer. For the interviewee, the interview situation itself is an arena for display of identity and self.

The information born out of interviews often comes in the form of stories that are relevant to the particular interview topics. These stories are situationally constructed during the interview by interaction between interviewer and the interviewee. A significant aim of the interview is to ensure that each interviewee provides relevant information to the interviewer. The open interview focused on making the respondents' voices heard and it relied on the respondents' own primary descriptions and their understandings and experiences.

The interviews were audio recorded and transcribed in full by the author. Transcripts were read repeatedly and coded thematically, as for instance working conditions, health problems, activities, and indications of identity-work and body work. Following McCracken (1988), the analysis consisted of a detailed analysis of language in each transcript and a comparison of patterns across all the transcripts. According to principles of abduction, hypotheses were formulated, tested against the transcripts, and if necessary reformulated. Search for deviant cases among the interviews was completed, but the respondents' stories were largely similar. The study is theoretically rigorous in the sense that interviewees were all well equipped to take part in discussions and they all held similar views about central topics like sick leave, work, and employment. The analysis may be described as a type of qualitative content analysis (Prior, 2011) with an emphasis on the interpretive framing of topics and contents of the stories told by the interviewees. Below, extracts from respondents are presented to document presented topics and experiences. To secure anonymity of the interviewees, the names following the extracts are cover names.

\section{Findings}

In our data material, every story about work and leisure activities, illness and sickness absence highlighted activity, in particular physical activity. The impression was that activities of various kinds seemed to be fundamental to their self and constituted the axis around which the interviewees' identity-work rotated. The findings are presented in three separate but related sections. The first concentrates on the interviewees' description of the factory and how they consider the wage work and workplace they are or were involved in. The second section concerns health problems and how the interviewees describe the relationship between their wage work and ill-health. The third section focuses on how sickness absence and premature retirement because of disability was experienced, legitimized, and time spent. 


\title{
Factory and Work Operations
}

The factory was originally a crucial source of employment within a relatively small municipality. It had more than 500 employees. After many reorganizations and workforce reductions during the last 15 years, there are now only 200 employees remaining. The factory produces for an international market and operates continuously. Thus, a large proportion of the employees work in shifts. The factory has different shift systems. Some work twelve-hour shifts. In addition, there is one week when they work every day. They start off with two days with twelve-hour shifts, then move to five days of afternoon shifts, and end with two night shifts. They work one week and one weekend before having off for a week. According to representatives from the management and the trade unions, this shift system is considered to be good by the youngest employees, but it is not given equal praise by the others. It is a shift system that is somewhat similar to the system used in the petroleum industry. It is a tough system particularly for those who gradually acquire health problems and are not so young anymore.

The work operations that most of our interviewees were involved in at the factory required heavy physical work. The work also required accuracy and capacity to function as part of a team. Several work operations were considered to be risky and the workers' behavior was regulated by rules designed to reduce risk. As the following statement indicates, this has been and still is heavy body work:

New machinery has automated some former work operations. But during the packing [of the goods] and loading [of the ships], sacks and pallets are damaged and have to be repaired and handled by us. Sometimes the machinery collapses. It is less heavy work now, but then again there are also fewer people. So in reality work is no less heavy than before (Atle).

In the quotation above, the interviewee claims that the work pressure and the demands for efficiency from the employer are much the same as earlier. New technology might have reduced the strain, but this effect is contradicted by higher demands for efficiency and fewer employees. As indicated in the following statement, this work situation has consequences for the employees' health:

\begin{abstract}
You have to work much more now in relation to the position you have. I have a $50 \%$ position, but I have to work faster now to reach it all, which I hardly do within my working hours. But this is a general tendency in working life nowadays. The burden on the worker is heavier. It is visible in this work place. Some people "hit the wall"; they do not manage the pressure. By this I am not saying that we can't work more efficiently. It is probably always possible to be more effective, but this is hard on people, particularly in extremely intensive work periods (Hans).
\end{abstract}

This increased work pressure is also elaborated by another interviewee. The following statement indicates that the work situation at the factory results in more stress:

The work pressure is tougher now than some years ago; it's more stressful. We have to handle more work operations; it is because we are fewer employees. The number of employees has decreased while the work load is the same (Sigurd). 
According to the interviewees, it is quite common to work overtime. It increases their payment and it provides those working overtime with a reputation of being reliable and having a strong will to work. As one interviewee stated, "I work overtime, quite often. I always have. I earn some extra [money]. I enjoy working and being with others. The overtime hours are voluntary" (Leif). So the pressure to work extra is not negatively considered.

Despite the fact that the workload has increased and several of the interviewees were critical to the reorganization processes and workforce reductions that had taken place at the factory during the last years, they considered their jobs to be very important to them. As the following statement indicates, work is seen as having an intrinsic value:

I like to work. I enjoy it and we are a good team down there at the moment. You realize how dependent you are on the job when you sit at home, waiting to recover [from an illness], and are not allowed to do anything (Ole).

Most of the interviewees claimed that the working environment at the factory was good. Several work operations depend on team work, and as the next statement suggests the interviewees' judgment of the working environment was closely related to how their working teams functioned:

We work in teams; it is the only way to get the job done. We depend on each other. The working environment is good now. We are working with deadlines and are always short of time. We depend on efficiency. Everybody has to do their job and cooperate (Fred).

The interviewees emphasized the expectation that every man loyally accomplished his job and considered himself as part of a working collective of equals. The message was clear in nearly every quotation: Teamwork among equals is what it takes to be an industrial factory worker today.

In general, these presented data indicate that the wage work the interviewees are engaged in is physically demanding for the individual worker and claims collective efforts from the workers. The workers have adapted to the demands of the production process within the factory, which is described as more stressful now than a decade ago. The working milieu is still considered as good and the job is significant and meaningful to them. They identify themselves as hardworking men who consider themselves as persons who "get on with it." However, the hard work tear on the body and illness occur as a result of strain from work and accidents. Illness may also occur because of other reasons. This will be presented in the next section.

\section{Health Problems and Manual Factory Work}

Most employees started to work in the factory as young men. At the time of the interviews, these men were between 45 and 60 years old. For some of them the employer had tried to find measures to their health problem that should prevent sickness absence, others had not. When the interviewees talked about their sick leave, they referred to how the wage work they had taken part in had marked their bodies and affected their health. They also talked about illnesses that only possibly could be related to their wage work. 
Among the illnesses related to work, back problems and shoulder and arm pains were most common, and as seen in the extract below some suffered from insomnia. The latter is a very common problem among shift workers (Åkerstedt, 2005):

I couldn't sleep when I came home after night shifts. The problem first began four to five years ago. I did not have any problems with the night shifts before that. You tolerate more when you are younger. I became ill. Later, I also got heart problems (Arne).

Some of the workers had been able to adjust their shifts or work operation to better fit their health condition. As indicated by the following statement, it is occasionally possible to avoid night shifts and gain health from it:

I became ill when not being able sleep after night shifts. It was so dreadful. I always had to get up to go to the toilet. I thought I had prostate problems and went to the GP. He said it was stress related, but took all the tests needed. I was lucky since the factory was able to change my shifts. I work days and evenings now, but not nights. My health problems have disappeared (Trond).

In some cases, the interviewees had illnesses, such as rheumatism or glaucoma, that were probably not caused by their job, but as the next statement suggests they still had consequences for their working capacity:

I have glaucoma. Glaucoma means that the pressure in the eye is out of order. I had an operation, but with complications. I was a crane operator. I had to stop doing that. I lost my peripheral vision. I was a danger to the others. I was transferred to the warehouse. I have relatives with the same illnesses (Morten).

Those who had ulcers believed their health problems were related to their jobs, to genetic dispositions, and to family situations. Some of those with chronic health problems worked half-time and had 50\% premature retirement because of disability. The following extract indicates that some had left the factory because the factory was unable to employ individuals with reduced working capacity:

I have pain in my back, shoulder and everywhere. My body is marked by wear and tear after many years (of hard work). But I could have kept on working if I was allowed. First I was moved to the storeroom, then to the reception, and then they didn't need me there either and there wasn't a job for me anymore. The job in the reception was fine-it suited me well—and was not too hard to my body; I handled it well. But they let a younger man with no health problems keep that job. I had to move to a department with heavy work; I did not manage very well. I miss having a job. I know I am able to work (Yngve).

Accidents rarely happen in the factory these days. The factory has implemented strict safety rules, and behavioral deviations from the safety guidelines are negatively sanctioned. But accidents still occur. As the next statement suggests, this man considers himself lucky since he survived falling down five meters onto the floor in a cargo hold: 
I fell down a ladder-five meters high. I only smashed my ankle. It was scary. I was lucky. I could have broken my neck or been killed. I wasn't permanently damaged (Ernst).

One of the interviewees broke his leg after falling down a staircase at home. Although he made a thorough recovery, his particular job required him to climb many flights of stairs. But for health and safety reasons, the GP recommended him to avoid such activities for some time and the management of his part of the factory allowed him to avoid climbing stairs and ladders while his leg was still weak. But this allowance generated problems in relation to his colleagues:

I got a working agreement at the factory. It was the health department at the factory that made it, but it was based on the GP's recommendation. But it was impossible to hold on to the agreement. I was the first to break it (and went back to sickness absence). We work in teams of four people and everyone has to rely on all the others. It is hard work. One of my colleagues came and said that he did not drive all the way from his home to the factory to work for others. I understand him, and I did not want to be a burden, but then what do you do when your health is poor.... (Frank).

The body fails and a work situation in which everybody depends on everybody makes it impossible to continue as an industrial worker. This interviewees' exclusion from work was caused by his failing body combined with an organizational structure of the work at the factory that he himself does not control. He is a member of a working collective where the solidarity among equals is valued.

Some of the interviewees who had developed chronic health problems told us that as the health situation worsened they gradually grew into a feeling of being unable to do their jobs as well and easily as before. They did not feel well. They tried to avoid sickness absences from work by asking the management to adapt the working conditions to their diminished physical capacities, for a short period of time. However, as the following statement indicates, the management refused to do this:

I asked the management if they could help me out. I felt ill and I was going to a specialist to be examined. I told the management that I felt bad and asked if they could help me out for a period-I felt that I could work if I could take it easier. I have worked there for 30 years. But no! So, I had to take a sick leave, and I am not the kind of guy that is on sick leave. If I had been that kind of guy I would have understood why they rejected my question. I would not have needed the sick leave if they had helped me out to begin with (Reidar).

This interviewee clearly stated that he is not the kind of man who is absent from work because of illness and, a person like that deserves something better than being forced on sick leave. He presents himself as a loyal worker with a strong work ethic who felt ill after 30 years of employment. He just needed some accommodations from his employer to avoid long-term sick leave.

Other demands for changes in working conditions were not refused. In one instance, an employee had a baby with severe disabilities and his family life became so stressful that he needed to take a sick leave to be able to deal with the situation at home. At the same time, the economics of his family situation required him to have a job. According 
to the following statement, on his request the factory transferred him to another department and a job that felt less demanding:

I am dependent on my job; my wife is also dependent on hers. We would not survive without our jobs. We need to get out of the house, be with others and have an ordinary day. Our family life changed dramatically after we had a disabled child. It is very demanding for all of us (Isak).

This person was accommodated for because he had a disabled child, which led to a difficult family situation. This indicated that there are moral elements that effect decisions in relation to making adaptions.

In general, the data presented so far reveal that workers get health problems of several kinds. Some of these health problems are caused by their wage work, but all of them have consequences for their working ability. Whatever caused their health problems, these workers express that they are the kind of persons who normally are hardworking and who would like to use their working capacity. They present themselves as the kind of persons who "get on with it." This is a part of their presented core self. The data also indicate that the factory is able to find work for some of its employees with health problems, but this is not common. Such accommodations are challenged when task adjustments run for long periods and especially when fellow workers start complaining about a colleague's work efforts or, as another study reveals (Gjernes, 2006), question the facticity or reasonableness of a colleague's illness. Bellaby (1999) found that persons with disabilities are often discriminated against in the employment market. Our data seem to support this finding. When the workers become ill they become excluded from the workplace and the working collective where a large part of their identity as hardworking and productive wage workers are constructed and maintained. But the exclusion from the factory floor does not seem to pacify them, as we will see in the next section.

\section{Legitimating Long-Term Sick Leave and Premature Retirement}

Many of the interviewees had returned to their jobs after successfully recovering from their illnesses or injuries during their time on long-term sick leave. Some had developed chronic illnesses and, after several periods of long-term sick leave, they were partly working and partly receiving disability benefits. A few of the interviewees had recently given up their job completely and were now receiving premature retirement because of disability. These persons had been through several long-term sickness absences. Although they did not see themselves as being unable to work, their bodies were simply unable to live up to the demands of factory life. The question here is how they legitimated sickness absence and premature retirement because of disability. These questions will be pursued in the following pages.

The data above have already revealed that according to the interviewees they prefer to avoid sickness absence and if possible without causing problems to their workmates. The workers value their jobs and working environment. Sometimes illnesses are of a kind that makes sickness absence unavoidable but as the following data reveal it is still possible to act and present what is considered as a core in ones' self. One person was signed into the hospital for surgery because of a prolapse in his back. The day before the 
surgery, he fell from a ladder and smashed his ankle. The surgery proceeded as planned and the employee was sent home to recover from both of these incidents. He spent the first few weeks recovering on the sofa and passing the time by reading. As he stated, "I was somehow bored, but people told me to read." Then he continued:

I could not walk, so I had to crawl around. I stitched together some pillows to put on my knees, and then I hammered together two terraces. I just had to crawl around on my knees and accept that I would use more time than I normally would. At this time I was not able to drive; my right foot didn't function because of the broken ankle. Then the car dealer called me. He said it was time for a last check up before the warranty on the car expired. I whittled a stick to replace my right foot and used it to accelerate the car. It was hard work to get there-200 km away. But I got the car sorted and went home again (Ernst).

This story shows that some people do manage to work-sometimes extraordinarilywhile they are on sick leave. This person describes how he used his creativity to make his body useful to have something meaningful to do while recovering. His story demonstrates efforts to engage in work and other activities the way healthy people do. What challenged his identity as a hardworking and active and creative person was the physical and creative passivity expected of him while waiting for the wounds and bones to grow completely. Instead he became a useful wage worker again. This worker had taken sick leave from his wage work, but he was expected to recover completely and return to his ordinary job. His health problems made him temporarily unable to be a part of his working team and incapable of doing the ordinary tasks required by his wage work. At the same time, he kept working. He used his creativity to construct his own assistive aids, which allowed him to work and make himself useful at home while he was recovering from a broken ankle and a back operation. He demonstrated strong will to work and a strong work ethic. In the face of his health problems, he defied his body by developing or maintaining his working capacity. To defy bodily messages in this way may function within a context of everyday life with its flexibilities, but it may be more difficult to do so in the context of factory work, where the working roles and tasks are standardized and regulated.

Some workers have ended up on premature retirement because of disability after experiencing several episodes of long-term sick leave. Now they were outside working life and they missed their jobs and colleagues. But as showed by the following statement, they still continued to work:

After they gave me premature retirement because of disability, I built a cottage and gave practical help to different local organizations in our area. I am asking people to let me help them out by giving me some work (Aksel).

This interviewee lives on premature retirement because of disability, but he would prefer to have wage work. He also stresses that he is working, even if he is not participating in wage work. Overall, his stories about his work demonstrate that, in his opinion, he has the capacity and will to wage work.

Another statement from another interviewee who recently acquired full premature retirement because of disability also indicates that he is capable of performing wage work: 
It is two years now, I think, one year on sick leave and one year on rehabilitation. I just have to accept that I am out of working life now, or at least the factory. During these two years I have spent very few days in a chair at home. The only reason to stay inside is bad weather. I am always outdoors. I have a dog; he is my hobby. Next week I am going to an interview. There is a man with a firm that needs someone to help him. I told him I would like the job. I need to do something and be together with people. I am also a member of a boat club. I organize and take part when we do voluntary work at the boat club (Simon).

This man is chronically ill and has to take his present health condition into consideration, but he is also searching for something to do. He demonstrates that he wants ordinary wage work; he does jobs for the boat club and he wants to do the same for the firm he mentions. It is central to his self to remain active and be a worker.

Several interviewees enjoyed outdoor activities of different kinds: some hunted, some enjoyed hiking tours, and some enjoyed skiing. Quite a few had a chalet (also called a second home) a few hours' drive from where they lived. They spent much of their leisure time there, repairing and working on the chalet and engaging in outdoor activities. These activities were considered to be healthy and relaxing. Leisure activities also express identities. One interviewee developed so severe health problems in his mid-forties that his position at the factory was reduced to $50 \%$ and he received $50 \%$ premature retirement. He was still intermittently long-term absent from work because of illness. As a result of the illness, his life had taken a new turn. Before he became ill, he enjoyed hiking tours that would count as extreme sport activities. He said that he took his first daughter on her first mountain trip when she was only a few months old. He would have carried on if his health condition had allowed him to, but deteriorating health forced him to move his attention in another direction-toward slower and shorter hiking trips. Although he missed the long and rough hiking tours, the following statement tells that the change that had occurred to him also made him look in new directions:

It was important for me to get to the top of high mountains. I also used to climb glaciers. The outdoor life I used to enjoy before I got rheumatism was kind of extreme when compared to what people normally do. I have been skiing in all directions on Spitsbergen. Now, I am looking down at the fauna, I see the beauty, the plants, I move slowly and not so far. I try to go outside as often as my health allows me. When the weather is bad I work with my photos on the computer. I watch birds. I am interested in ornithology (Magne).

This is the self of a person who enjoyed using his body in extreme sports and rough outdoor life. He is a kind of person who appreciates physical struggle and risk, but he is not able to do it anymore and as such the illness and exclusion from such activities could represent a threat to his identity and self. But this man has replaced his former extreme sport activities with new ones and these new activities have something in common with the former because they concern nature and outdoors even though he had to transform his identity slightly by finding pleasure in slow tours in the mountains and peaceful bird watching. The meaning of his outdoor life and leisure activities had to change in some ways, but not completely. This was also how he could spend his time when absent from wage work, a way considered as healthy and building for the body.

The interviewees often made a distinction between body and mind when they reflected on how they experienced being excluded from working life by sickness absence 
or premature retirement because of disability. Their will to work is part of the identity of an industrial factory worker. But for many of the interviewees, their bodies operated different from their minds. Their bodies worked against their will to work. According to Garro (1994), when informants separate mind and body, they separate identity from the event that impinges upon it. This separation is captured in the following quotation:

The body did not function as it should, I was freezing all the time, felt cold, and the body was not well. My GP said my body was stressed. I mean, I wanted to work, but the body said stop (Knut).

This statement is about the legitimacy of the illness and sickness absence. Something has put the interviewee out of action and it is beyond his ability to control this. The interviewees on premature retirement because of disability or sickness absence also emphasized their attempts at postponing premature retirement as long as possible. As demonstrated in the next statement, they simply refused to accept it until it was obvious that there was no way to reconcile the problems of poor health and the demands of factory work:

It started with the usual wear and tear problems, back pain, pain in shoulders and neck. The GP said I had to get a working agreement; there were some work operations I was unable to do. Today I am on disability but it is not because I wanted it to end like this. The premature retirement because of disability was almost forced on me by the GP. Yes, I decided to apply for the benefit and as such it was my decision, but I did it because this time I chose to listen to the GP's advice (Peder).

The impression from this quote is that the GP has recommended this person to apply for premature retirement for quite a while, but that he has refused to take it into consideration. He had chosen to work as long as possible and therefore experienced long-term sickness absence several times. The interviewee communicated to us that he wanted to keep his job and continue as a wage worker, despite his poor health.

The interview data outlined above demonstrate that the interviewees in general consider themselves as hardworking men, with a strong work ethic. They are willing to work where employed and other relevant places. This characterized the identity the interviewees presented before they became ill. This characterizes their identity presented after they became ill as well. They seem to refuse to surrender to a master status as sick. But the identity as a hardworking physically strong and active person became challenged by the illnesses and the sickness absence, and identity-work was therefore needed. Sickness absence seems to be associated with passivity or inactivity, sometimes laziness, low working capacity, and low work ethic. This is the opposite of what these manual workers say they are and want to be. It has been vital for them to demonstrate that although one is incapable of some type of work, one is not disabled or useless as a worker and producer.

The data indicate that these interviewees refuse to accept the reduced status that comes with being on long-term sick leave or premature retirement because of disability. Therefore, they become significantly occupied with presentation of their self-image. During sick leave, they adopt a number of activities and make themselves visible as more than ill persons. It seems to be pertinent for them to emphasize identities other than those associated with being ill. Their involvement in other kinds of work reduces 
the adverse effects to the images they have of themselves, effects brought about by being forced out of the factory because of illness or injury.

These interviewees emphasize that they do not lack the will to work, but their bodies refuse or set limits to the kind of work they can do. Moreover, the work organization-which means the organizational structure of the factory-also limits their abilities to do wage work. The interview data illustrate the interviewees' desire to demonstrate the kind of individuals they are. They tell their stories in ways that present their selves as active working selves. As such they are performing identity-work not only during the interview but also with reference to the everyday life they report about.

Parsons' (1951) conception of the sick role or a disability perspective might be considered as alternative analytical approaches for this study. Both have their merits, but they are also analytically and empirically somewhat restricted in relation to our empirical material. Parsons (1951) introduced his theoretical and ideal typical concept of "sick role" as a functional component of the social system. It represented a contract between the sick person, medicine, and society, while it also recognized sickness as a simultaneous biological or medical and social phenomenon. By entering the sick role, patients were granted rights and privileges provided that they complied with the role's normative requirements. The sick role was temporary and the purpose of adopting it was to get well and resume ordinary social functions. Turner (2004) maintains that acute illness is the core of Parsons' sick role concept and so does Thomas (2007). Parsons thought it unfortunate if the sick role and a social identity as sick should merge. In spite of this, the Parsonian sick role concept has been criticized by several scholars (Bury, 1982, 1997; Charmaz, 1994; Shilling, 2002; Varul, 2010). Empirically it does not fit the sick role of patients with chronic conditions (Strauss, 1975) and analytically it does not address the moral problem of a lasting or permanent sick role as master status (Gerhadt, 1989). The employees in this study had various kinds of health problems. Some were chronically ill, but periodically able to work, others were on long-term sick leave, but might return to work, and a few were formally classified as disabled because of permanent incapacitating health problems. What they had in common was that they had to adopt a sick role for long periods. The sick role they adopted was not just a contract between them, their doctor, and society; their sick role also involved their employer, their families, friends, and others, and this multiple involvement lasted for long periods. For a few of them, it was permanent. Finally, and most obviously in this article, they fought against the master status the sick role represented, a master status that might restrict other subsidiary roles incompatible with a sick role. Hence, they did whatever possible for not becoming associated with the sick role. Another criticism of Parsons (1951) came from Garfinkel (1984) who accused Parsons of wrongfully designing actors as "cultural dopes." Our interviewees did not act as cultural dopes. Instead they were active and inventive; they tried to cope with their health conditions and life situations and to develop satisfying lives in spite of failing health and other obstacles they experienced in connection with their sickness.

Individuals who are chronically ill or on long-term sick leave may have similar experiences as individuals categorized as disabled. In our study, using the term disability instead of sickness to refer to the health problems of our interviewees would not be quite adequate, since disability is ordinarily thought of as a permanent condition (Bury, 1997). Most of our informants were in a sick role for long periods, but not permanently. However, they share some problems with disabled persons. This includes the fact that 
they might be able to work if their work situation had been tailored to their physical capacity and their wish to draw attention away from sickness as a master status or disability as a social or medical identity category. This study also shows how persons on long-term sick leave engage in activities that show them as active, enterprising, and able individuals. This is very much in correspondence with the focus of recent disability research (Thomas, 2007).

\section{Conclusion}

The data presented in this article demonstrate that male employees experiencing longterm sickness absence and premature retirement because of disability were significantly preoccupied with their identities as wage workers and as active persons who "get on with it." This is a fundamental part of the self they present and they seemed to be preoccupied with protecting this self.

Their presentations of their self were done in a context of moral ambiguity. They were talking about how illness and ill-health had made them incapable of conducting their ordinary job, but sickness absence is as Bellaby (1999) has pointed out morally loaded, and so is premature retirement because of disability and this is evident in the way these manual workers argue to legitimate their sickness absence. The moral ambiguity of sickness absence seems to demand identity-work. Identity-work is performed to protect their selves and identities. It is work performed to show to yourself and others who you are, who you are not, and who you want to be (Parsons et al., 2008).

These factory workers demonstrate that wage work has produced what Bellaby (1999) calls physical "footprints" on their bodies and they deserve some respect for this offer. They present themselves as hardworking producers, loyal colleagues, and active citizens. They also act as responsible persons who take care of their own health by complying with doctors' orders. These men took their illnesses seriously and recognized their health conditions, but they did not surrender completely to an identity as sick and incapable of work. Therefore, illness and sick leave do not result in passivity and idleness; instead, it triggers other forms of activity and inventiveness. If ill-health disallowed former activities-e.g., mountain climbing or employed work-these activities were replaced by other types of work or activities. This replacement did not seem to result in loss of self. Instead it led to efforts to prevent loss of self; the interviewees developed strategies and procedures to display alternative and acceptable selves.

Manual workers like the interviewees we have met here are body workers (Wolkowitz, 2006). They are workers who use their physical body to conduct wage work and when they exercise to gain strength and health. Bodily activity is vital to them, because it is necessary in their job and it is also vital because it is part of their self. To keep being physically active when too ill to attend the job is not only a way of fighting boredom, it is also embodied identity-work. It might also be related to masculinity. As described, it is reasonable to understand the interviewees' wage work as risky, intensive, and physically demanding. These work characteristics are closely connected to certain conceptions of masculinity, and indicators of masculinity may count as cultural capital in milieus where physical strength is highly valued (Lovell, 2004).

The data also indicate that wage work plays a significant role in the interviewees' everyday lives and is central to their identity-work. This contrasts with arguments from 
Bauman (1998), Beck (1992, 2000), and Sennett (2004), who claim that work has lost its prominent position in contemporary society. But it accords with studies by Doherty (2009) and Felstead et al. (2005) and Shilling (2005) who argue that work still fulfills important personal and social needs. To these factory workers the wage work was central because it gave income, represented a social arena, and gave membership in a working collective. But wage work also made them producers of goods; they were individuals who contributed to upholding of the factory and of workplaces. The meaning of being a producer is also evident in the work tasks they engaged in when on sick leave. It was also evident when we consider the work and the activities engaged in by those who have been excluded from the workplace because of disabilities. The data also indicate that the demands to an able-bodied industrial worker have become tougher. The demands for efficiency are heavier and factory's willingness or ability to adapt to workers bodily incapacities or to find new kinds of work to them has changed. Over time, the strain of the hard physical work may produce health problems, while the employer cannot use workers with limited working capacity. A probable result is that workers more easily may be excluded from employment. It also means that the nature of the health problems that take industrial workers out of employed work is relative to the working conditions of today's industrial plants.

In contemporary society, sickness absence in general is increasingly becoming dubious and negatively considered. The identity-work presented in this article may be a consequence of this cultural discourse. Employees who after several years as manual workers and who see themselves as individuals with a high work ethic and a strong sense of loyalty toward their employer and consider themselves to be producers with a high value need to defend themselves when they become ill. The situation of our interviewees is not the same as George's situation in Cato Wadel's (1973) study from the late 1960s, but the situations are similar. George was unemployed and had to struggle hard to withhold identities fundamental to him. As the title of the book "Now, who's fault is that" implies, unemployment was not his fault and it was important to communicate that. In the present study, it is male industrial workers who after several years of employment experience ill-health and long-term sickness absence. They express that their situation is not according to their own wish and therefore not their own fault. They feel they have to defend their self to maintain self-respect and to claim respect from others.

\section{References}

Åkerstedt, T. (2005) 'Shift work and sleep disorders'. Sleep, 28(1): 9-11.

Allen Collinson, J. (2006) 'Just "Not academics”? Research administrators and contested occupational identity'. Work, Employment and Society, 20(2): 267-288.

Atkinson, P. and Housley, W. (2003) Interactionism. London: Sage.

Bauman, Z. (1998) Work, consumerism and the new poor. Buckingham: Open University Press.

Beck, U. (1992) Risk society: towards a new modernity. Cambridge: Polity.

Beck, U. (2000) Individualization: institutionalized individualism and its social and political consequences. London: Sage.

Bellaby, P. (1999) Sick from work. The body in employment. Aldershot: Ashgate.

Blaxter, M. (2004) 'Life narratives, health and identity'. In: D. Kelleher, and G. Leavey (eds.) Identity and health (pp. 170-199). London and New York: Routledge. 
Blekesaune, M. and Pedersen, A. W. (2006). 'Sykefravær: Innfallsporten til permanent trygding?' [Sickness absence: a gateway to permanent welfare benefits.] In: T. Hammer and E. Øverbye (eds.) Inkluderende arbeidsliv?: erfaringer og strategier. [Including working life? Experiences and strategies (pp. 142-162).] Oslo: Gyldendal akademiske.

Bloor, M. (2011) 'An essay on "health capital" and the Faustian bargains struck by workers in the globalized shipping industry'. Sociology of Health and Illness, 33(7): 973-986.

Bury, M. (1982) 'Chronic illness as biographical disruption'. Sociology of Health \& Illness, 4(2): 167-182.

Bury, M. (1997) Health and illness in a changing society. London: Routledge.

Charmaz, K. (1983) 'Loss of Self: a fundamental form of suffering in the chronically ill'. Sociology of health \& Illness, 5(2): 168-195.

Charmaz, K. (1994) 'Identity dilemmas of chronically ill men'. The Sociological Quarterly, 35(2): 269-288.

Charmaz, K. (1999) 'From the "sick role" to stories of self'. In: R. J. Contrada and R. D. Ashmore (eds.) Self, social identity and physical health (pp. 209-239). Oxford: Oxford University Press.

Charmaz, K. (2000) 'Experiencing chronic illness'. In: G. Albrecht, R. Fitzpatrick and S. Scrimchaw (eds.) Handbook of sociological studies in health and medicine (pp. 277-292). London: Sage.

Collinson, D. L. (2003) 'Identities and insecurities: selves at work'. Organization, 10: 527-547.

Cooley, C. H. and Schubert, H.-J. (1998) On self and social organization. Chicago: University of Chicago Press.

Doherty, M. (2009) 'When the working day is through: the end of work as identity?' Work, Employment \& Society, 23: 84-101.

Felstead, A., Jewson, N. and Walters, S. (2005) Changing places of work. Basingstoke: Palgrave.

Garfinkel, H. (1984) Studies in ethnomethodology. Cambridge: Polity Press.

Garro, L. C. (1994) 'Narrative representations of chronic illness experience: cultural models of illness, mind, and body in stories concerning the temporomandibular joint (TMJ)'. Social Science \& Medicine, 38(6): 775-788.

Gerhadt, U. (1989) Ideas about illness. London: Macmillan.

Gjernes, T. (2006) 'Styring, forhandling og absorbering. Om midlertidig tilrettelegging av arbeid i en industribedrift'. [Governance, negotiation and absorption. On temporary adjustment of work in an industrial plant'.] Fagartikkel. Respekt, 2: 49-51.

Gjernes, T. and Pettersen, L. T. (2009) Tilbake til arbeidslivet. En studie av hvordan IA-avtalen praktiseres ved to offentlige sykehjem og en industribedrift. [Back to work. A study of how the IA agreement is practiced at two public nursing homes and an industrial planet.] Rapport 1. Bodø: Høgskolen i Bodø.

Goffman, E. (1969) The presentation of self in everyday life. London: Penguin.

Kelly, M. (1992) Colitis. London: Routledge.

Kelly, M. P. and Millward, L. (2004) 'Identity and illness'. In: D. Kelleher and G. Leavey (eds.) Identity and health (pp. 1-18). London and New York: Routledge.

Lovell, T. (2004) 'Bourdieu, class and gender: the return to the living dead'. In: L. Adkins and B. Skeggs (eds.) Feminism after Bourdieu (pp. 37-56). Oxford: Blackwell.

Marx, K. and Engels, F. (1970) The German ideology. London: Lawrence and Wishart.

McCracken, G. (1988) The long interview. Newbury Park: Sage.

Mead, G. H. (1934) Mind, self \& society. Chicago: University of Chicago Press.

Miller, P. and Rose, N. (2008) Governing the present. Cambridge: Polity. 
Ose, S. O., Jensberg, H., Reinertsen, R. E., Sandsund, M. and Dyrstad, J. M. (2006) Sykefravcer. Kunnskapsstatus og problemstillinger. [Sickness absence. Knowledge status and problems.] Rapport. Sintef Helse.

Parsons, J. A., Eakin, J. M., Bell, R. S., Franche, R.-L. and Davis, A. M. (2008). 'So, are you back to work yet?" Re-conceptualizing "work" and "return to work" in the context of primary bone cancer'. Social Science \& Medicine, 67: 1826-1836.

Parsons, T. (1951) The social system. London: Routledge \& Keagan Paul.

Prior, L. (2011) 'Using documents in social research'. In: D. Silverman (ed.) Qualitative research (pp. 93-110). London: Sage.

Riach, K. and Loretto, W. (2009) 'Identity work and the "unemployed" worker: age, disability and the lived experience of the older unemployed'. Work, Employment and Society, 23: 102-119.

Sennet, R. (2004) Respect: the formation of character in an age of inequality. London: Penguin.

Shilling, C. (2002) 'Culture, the sick role and the consumption of health'. British Journal of Sociology, 53(4): 621-638.

Shilling, C. (2005) The body in culture, technology and society. London: Sage/TCS.

Shilling, C. (2008) Changing bodies. Habit, crisis and creativity. LA, London, New Delhi, Singapore: Sage.

Strauss, A. (1975) Chronic illness and the quality of life. Philadelphia, PA: Mosby.

Thomas, C. (2007) Sociologies of disability and illness. New York, NY: Palgrave Macmillan.

Turner, B. (2004) The new medical sociology. New York, NY: Norton.

Varul, M. Z. (2010) 'Talcott Parsons, the Sick Role and Chronic Illness'. Body \& Society 16, (72): 72-94.

Waddell, G. and Burton, A. K. (2006) Is work good for your health and wellbeing? London: TSO.

Wadel, C. (1973) Now, whose fault is that? The struggle for self-esteem in the face of chronic unemployment. St. John's, Newfoundland: Institute of Social and Economic Research, Memorial University of Newfoundland.

Wolkowitz, C. (2006) Bodies at work. London: Sage. 